\title{
Barnehagen som skrivende organisasjon
}

Helene Berntsen Brennås

Nardosletta barnehager, bp6@trondheim.kommune.no

\section{Sammendrag}

Denne artikkelen vil, gjennom posthumane innganger, gi et bilde på hvordan skriving som metode kan synliggjøre og dekonstruere dominerende diskurser, og betydningen overskridelser kan ha for pedagogisk praksis. Jeg har vært opptatt av å gå inn i skriving som overskridende metode, som kunnskaping i, om og med egne praksiser. Gjennom utforskning av teoretiske innganger i møte med datamaterialet er det tre sentrale trekk som utpeker seg når barnehagen som skrivende organisasjon tematiseres, det er betydningen av dekonstruksjon, affektive kaosorienterte forståelser og ontologiske mellomrom for bevegelse av handlingsmønstre i pedagogisk praksis.

Er det slik at ved å dekonstruere dominerende diskurser, gjennom affektive kaosorienterte forståelser, skapes det rom for mulige ontologiske mellomrom - som videre kan føre til overskridelser i pedagogisk praksis? Det handler i så måte om hvordan vi gjennom skriftliggjøring av de små og nære hendelser i det levende livet i barnehagen kan dekonstruere dominerende diskurser og bryte etablerte handlingsmønstre, gjennom skrivehistorier som diffraksjonsapparat. Gjennom affektive kaosorienterte forståelser befinner vi oss $i$ et mellomrom mellom det som er og det som kan bli, og i dette mellomrommet forstyrrer og utfordrer vi pedagogiske praksiser som "tas for gitt". På bakgrunn av det kan man gjennom denne studien tenke barnehagen som lærende organisasjon med skriving som overskridende metode som kompetansestrategi.

Mine funn kan tyde på at skriving som metode gjennom ovennevnte prosesser kan bidra til overskridelser, som deretter skaper mulighetsbilder for å styrke barnehagen som pedagogisk institusjon, samtidig som det åpner opp innganger til å nytenke kunnskapsstrukturer -og innganger til barnehagefaglig arbeid.

Nøkkelord: Skriving, diffraksjonsapparat, materialitet, agentskap, kompetansestrategi.

\section{Abstract}

This article will, through post-human entrances, give a picture of how writing as method can highlight and deconstruct dominant discourses, and the meaning exceedances may have for educational practices. Through exploration of theoretical entrances in the face of the data, there are three key traits that stand out when kindergarten as a writing organization is discussed, it is the importance of deconstruction, affective chaos- oriented understandings and ontological in-between spaces for movement of behavioral patterns in educational practice. It is in this context of how we through transcribing the small and close events of the living life in kindergarten can deconstruct dominant discourses and break established 
patterns of behavior, through writingstories as diffraction apparatuses. Through affective chaos-oriented understandings we find ourselves in a space between what is and what could be, and in this space we interfere and challenge educational practices "taken for granted". On this basis, through this study, it opens up to think kindergarten as a learning organization with writing as method as competence strategy.

Keywords: Writing, diffraction, materiality, agency, competence strategy.

\section{Innganger}

Datamaterialet som ligger til grunn for denne artikkelen er hentet fra eget masterstudie i 2015: Barnehagen som skrivende organisasjon, og må sees som en engasjering i et utvalg profesjonsutøveres veiledede skriveprosesser, som jeg selv er en del av. Skriveprosessene har pågått i fire år som eksperimenteringer av både form og sjanger, slik har vi utfordret den tradisjonelle narrative strukturen: "A text cannot belong to no genre, it cannot be without or less a genre. Every text participates in one or several genres, there's no genreless text; there is always a genre and genres, yet such participation never amounts to belonging"(Derrida, 1980, s.65 i Rhodes (2001, s. pretext)).

Det teoretiske rammeverket er inspirert av, og hviler på poststrukturell tenkning om språk gjennom filosofen Jaques Derrida hvor begrepene dekonstruksjon og différance er sentrale. Videre vil kritisk diskursive teorier gjennom Michel Foucault belyses, mens jeg gjennom Gilles Deleuze og Felix Guatarri, og Karen Barad utvider mer mot materielle og affektive perspektiver. Her vil Deleuzes begrep rhizome og (til)blivelse(becoming), og Karen Barads teorier om intra- aksjon og diffraksjon åpne mulighetsrom for meg. Studien kombinerer i så måte posthumane og poststrukturelle perspektiver som tankeverktøy til å tenke med (Deleuze og Guattari, 1987) gjennom diskursive og materielle innganger når jeg utforsker skriving som metode. Tenkning knyttet til skriving som metode tar utgangspunkt i blant andre Laurel Richardson og Jeanette Rhedding-Jones, som i likhet med Barad henter inspirasjon fra Derrida. Hensikten med dette teoretiske rammeverket vil være å se på betydningen av språkets rolle i diskurser, og hvordan diskursene iverksettes og materialiseres gjennom skriftliggjøring av og i pedagogisk praksis.

Richardson (2000, s. 924) omtaler skriving som en dynamisk og kreativ prosess hvor man skriver for å oppdage: for å lære noe man ikke visste før man skrev det. Vi kan forstå dette som en motsats til å skape nye sannhetsfortellinger, slik at ny kunnskap kan skapes. Men hva er virkeligheten, hvordan få kunnskap om virkeligheten, og hvilke metodologiske tilnærminger kan støtte oss i å analysere kunnskap? Barad (2007) hevder at verden og våre prosesser for å skape kunnskap om den ikke går an å skille. Perspektivene handler slik sett ikke om verden, men er deler av verden. Gjennom et posthumant ontologisk utgangspunkt i denne studien rettes ikke fokuset mot en sannhet om hva skriving er, men åpner innganger til hva skriving kan gjøre. Slik kan jeg tenke denne studien som onto- epistemologisk, som en betegnelse for at vitenskapsteori og metodologi sees sammenhengende gjennom det teoretiske rammeverket, slik Barad (2007) fremskriver eksperimenteringer gjennom materiell-diskursive møter for å forsøke å forstå hvordan ting gjennom agentskap skapes i verden. På denne måten utfordres antroposentriske forskningstilnærminger ${ }^{1}$ (Hultman \& Lenz Taguchi, 2010). I denne artikkelen får dette betydning på flere områder. På den ene siden berører det deltakerne og datamaterialet i studien, når skriftliggjøring av pedagogisk praksis tematiseres. Samtidig omfavner skriving som metode meg i denne sammenheng, om mulighetene for oppdagelser i mine skriftlige møter, med og i bevegelse mellom teorier og datamaterialet. Vi kan

\footnotetext{
${ }^{1}$ Antroposentriske forskningstilnærminger plasserer mennesket(forskeren) i sentrum og som overordnet materialiteten. Barad (2007) problematiserer dette og slik utfordres antroposentriske tilstander av intra-aktive teorier.
} 
tenke gjennom Hultman og Lenz Taguchi (2010), hvordan det i disse møtene blir skapt noe nytt sammen med datamaterialet. Skriving vil i så måte kunne forstås som både metode, teori og praksis. Ser man på skriving som både metode og overskridende praksis byr det på en diskusjon om sjanger, språk og meg selv, slik Rhodes (2001) også uttrykker det når han skriver gjennom Derrida: "This text then might be said not to "belong" to a genre of research, but it does intend to participate in it". Slik bryter jeg med den narrative strukturen, og utforsker uforutsette mulige innganger til barnehagen som skrivende organisasjon med en hensikt om å åpne opp for produktive prosesser som beveges.

Skriving som metode innebærer skriving av både autobiografisk og autoetnografisk art. For å jobbe mot måloppnåelsen om en lærende organisasjon fokuserer vi på autoetnografiske tilnærminger, som tradisjonelt er definert som en form for selvrefleksjon og skriving som utforsker skribentens egne erfaringer og binder dette til en videre kulturell, politisk og sosial sammenheng. På den måten kan vi skape koblinger mellom barnehagens mandat og pedagogisk praksis, og etablerer oss selv og andre som viljesaktører i og gjennom det (fenomenet) vi skriver om. Autoetnografier handler da samtidig om både seg selv og andre, og muliggjør det å bevege seg og navigere i ukjente rom (Reinertsen, 2015). Min erfaring er at dette gir rom for bevegelser, da vi gjennom poststrukturelle og posthumane innganger sprenger sjangeren åpen, og derav slik Rhodes (2001, s. 75) uttrykker det, hvordan vi slik sett posisjonerer oss selv gjennom å skrive som de som observerer og deltar i skriveprosesser, samtidig som vi istandsetter oss til å forstå og teoretisere de prosessene som pågår. Slik forstår jeg også denne artikkelen, som skriftliggjøring av egen praksis som framstilles i en vitenskapelig sammenheng, og på den måten kan kunnskap gjennom skriving som både metode, teori og praksis utfordres og understrekes. Samtidig kan jeg tenke slik Ehn og Klein (1994, s. 10) skriver det: «Å studere andre er i viss mening det samme som å studere seg selv».

I følge Haraway (2008) i (Hultman \& Lenz Taguchi, 2010) kan alle materialiteter gjøres til medskapere som ikke bare er i verden, men som også virker $i$ og med verden. Denne artikkelen blir slik sett til som et resultat av at jeg har sett, lest og virket med. Et posthumant og diffraktivt engasjement innebærer altså at jeg ikke kan avgrense meg fra det jeg gjør, men heller virke, tenke og bli til med i en virkelighet og praksis her og nå, slik Haraway (2008) sier det: "As you read the data diffractively you install yourself in an event of 'becoming- with' the data" (Hultman \& Lenz Taguchi, 2010, s. 537). Datamaterialet vil i denne studien leses diskursivt, diffraktivt, materielt og som "lines of flights". Jeg forstår, gjennom Deleuze og Guattari (1987), "lines of flights" som dynamiske og kontinuerlige bevegelser i tenkningen, og det er i det landskapet jeg føler meg hjemme. Linjene kommer flyvende når jeg skriver, foreløpige, ikke som konkreter tilhørende i en struktur, eller i en bestemt sjanger. Men, som (til)blivende, med meg- underveis i møte med datamaterialet, tenkning som hele tiden setter sammen nye og tar fra hverandre ideer, igjen og igjen (Deleuze \& Guattari, 1987). Slik kan jeg tenke denne studien som nomadologi, og stå i det åpne og tillate seg å være i bevegelse - på tross av dominerende diskurser. Som Deleuze og Guattari (1987, s. 140) skriver det: "[...] nomadism is a movement, a becoming that affects sedentaries, just as sedentarization is a stoppage that settles the nomads". Dette ligger så praksisnært for meg, for det er denne tenkningen om "lines of flights" vi etterstreber i praksis, det er slik skrivehistorier kan bli til omdreiningspunkt, det er slik vi som nomader i pedagogisk praksis kan forflytte oss, om vi våger å stå i uforutsigbare prosesser som kan løfte fram både kompleksiteten, spenningsforhold og dilemmaer, som videre gir oss muligheter for å oppløse dikotomier, og dekonstruere gjennom, med og $i$ praksis. Det er samtidig viktig å være oppmerksom på, slik Deleuze og Guattari (1987) påpeker det, det finnes ingen garanti for at "lines of flights" åpner opp for forandringer, vi vet ikke hvor de leder oss, de kan lede oss hvor som helst, og ingen plass.

"Lines of flights" skaper territorier, og oppstår mellom territorier slik jeg leser Deleuze og Guattari (1987), og slik kan det tenkes at ingen territorier anses som helt faste eller stillestående. Dette kan forstås som en del av den nomadiske tenkningen ved å tenke at samtidig som "lines of flights" tillater territorier å eksistere, destabiliserer de også den territoriale karakteren. "Lines of flights" er ifølge 
Deleuze og Guattari (1987) en iboende bevegelse av deterritorialisering, og slik kan man altså omtale deterritorialisering som noe som består, og endres av "lines of flights". "Lines of flights" kan i så måte produsere nye territorier som også vil inneha deterritorialisering. Deleuze og Guattari (1987) beskriver prosessen rundt deterritorialisering i $A$ Thousand Plateaus hvor jeg leser deterritorialisering som et $\varnothing$ nske om å frigjøre faste relasjoner samtidig som man bringer inn nye. I sammenheng med denne studien når jeg undersøker skriving som metode gjennom og med posthumane perspektiver, og samtidig tenker skriving som en nomadisk aktivitet, "frigjøres" aktiviteten fra å ensidig omtales som noe menneskelig, til noe som også inkluderer påvirkning og intra- agering med ikkemenneskelige materialiteter i omgivelsene. Kanskje er det slik at deterritorialisering i seg selv best kan forstås som noe bevegelig som produserer forandring? I så måte finner jeg det relevant å se det i sammenheng med Barad (2007) sin beskrivelse av diffraksjonsapparat med den hensikt å produsere bølger gjennom å bryte med, og intra- agere med "havstrømningene".

\section{Skriveprosesser som datainnsamling}

Personalet i barnehagen er organisert i systematisk veiledede skrivegrupper, og skrivehistorier (Richardson \& St.Pierre, 2005) som synliggjøres i denne artikkelen er skrevet med en måneds mellomrom, henholdsvis september og oktober 2014, hvor det ble gjennomført en veiledet skrivegruppe i mellomtiden. Skrivehistoriene jeg har gått inn i er skrevet av en ufaglært assistent, Assistent $A$, og berører tematikk hvor assistenten opplevde det som strevsomt å møte enkeltbarnets uttrykk. Videre har jeg også gått inn i det øvrige personalets refleksjoner knyttet til egne oppdagelsesprosesser. I veiledning ble Skrivehistorie 1 l $\varnothing \mathrm{ftet}$ til felles refleksjon da flere av personalet gjenkjente frustrasjonen og utfordringen. Videre skrev alle i den veiledede skrivegruppen en skrivehistorie knyttet til å møte det samme barnets uttrykk på bakgrunn av Skrivehistorie 1 skrevet av Assistent $A$. Utvalget av datamaterialet er gjort på bakgrunn av en tenkning om at skrivehistoriene berører en del av barnehagens diskursive praksis, hvordan barn i barnehagen hele tiden må forholde seg til diskurser som de er en del av. I tillegg til selv å bidra til diskurser blir barn også konstituert av andre diskurser, ut ifra forestillingene om barn og barnehager som dominerer i bestemte sammenhenger. Med andre ord kan man si at barn blir formet av hvilke handlingsmuligheter de får tilgang til i ulike miljøer (Nordin-Hultman, 2004). Skrivehistoriene synliggjør bevegelser slik Lenz Taguchi (2004) eksemplifiserer motstridende diskurser: ved å vise til hvordan man i en sammenheng tenker og handler på en måte, mens man i neste sammenheng kan tenke og/eller handler på en annen måte. "Vi tenker innenfor det som er kulturelt mulig" (Nordin-Hultman, 2004, s. 170). På samme måte er ikke barna på en spesiell måte, de blir, ut fra de mulighetene og diskursene som handlingsrommet byr på. Slik jeg ser det, byr dette på en framstilling av dekonstruksjon som sentralt for å avdekke diskursene i pedagogisk praksis.

\section{Pedagogiske prosesser som (til)blivelser}

I tradisjonell forstand ville vi gjennom skriving som overskridende metode hatt fokus på å snu speilet: å vende blikket fra barn, og mot oss selv for å forstå mer om hvem vi er i møte med barn, barndom og barnehage. I en diffraktiv tenkning kan en forstå at ved å se oss selv i speilet ser vi kun oss selv idet speilet kaster lysstrålen like hel tilbake. Mens et speil slik bare vil forflytte det samme til et annet sted, vil et prisme kunne fungere motsatt. Et prisme kan få lysstrålen til å gå andre retninger, og slik bryte den opp i et helt nytt og uventet fargespekter. Den vil altså bryte og vende i stedet for å reprodusere det samme i all evighet (Barad, 2007). I denne sammenheng kan skrivehistorier forstås som omdreiningspunkt, hvor diffraksjon støtter oss i å vende fokus bort fra det som er og mot det som kan bli, gjennom diffraksjon med skrivehistoriene. Jeg vil utprøve denne tenkningen ved å gå inn i Skrivehistorie 1, hvor Assistent A skriver følgende om sitt møte med enkeltbarnets uttrykk:

Thea (2,3år) er blitt storjente på Hvitveis. I løpet av sommeren har det skjedd mye med språket hennes. Hun har fått et større ordforråd, formulerer setninger og bruker språket $\mathrm{i}$ flere situasjoner enn før. Tidligere kunne Thea ofte bruke "sutrelyd" når det var noe hun ville 
uttrykke. Det forekommer fremdeles, men siden det verbale språket hennes nå begynner å falle mer på plass bør hun få mer støtte til å bruke det i alle situasjoner for å uttrykke $\emptyset$ nsker/behov og hevde sin rett.

Deleuze og Guattari (1987) er opptatt av hvorvidt kunnskap begrenser eller utvider vår tenkning, og hvordan kunnskap virker. Slik våre kunnskapstradisjoner er konstruert kan man tenke at det begrenser forståelsen av barnets muligheter til å bli forstått på andre måter. Kunnskap kan i så måte virke begrensende på tenkningen knyttet til å se barnet på nye og andre måter, hvis vi forstår menneskelig aktivitet som (til)blivelsesprosesser. I skrivehistoriens refleksjonsdel stiller Assistent $A$ seg følgende spørsmål: "Hvordan støtte Thea i å bruke det verbale språket mer? Språkgrupper kan ha en gunstig virkning". Det som kan fremstå som en uskyldig tekst, har kraft til å produsere både makt og virkeligheter, slik Derrida (1976) hevder at språk og ord er hverken uskyldig eller nøytralt, og spørsmålet Assistent $A$ stiller seg her skriver frem et eksempel på en del av kunnskapstradisjonen. Richardson (2000, s. 929) beskriver det slik: "Language is not the result of one's individuality; rather, language constructs the individual's subjectivity in ways that are historically and locally specific. What something means to individuals is dependent on the discourses available to them". Når personalet i barnehagen gjentar bestemte handlingsmønstre konstitueres det diskurser om og i barnehagen, og det virker utenkelig at vi kan velge fritt hvordan vi vil handle gitt at vi alltid vil være underordnet diskursive reguleringer. Det vil være interessant å se på hvilke produksjonsmuligheter språket gir, om dekonstruksjon og diffraksjon som redskap til å tenke med kan forstyrre oss i vårt møte med skrivehistorier istedenfor å gjenta etablerte handlingsmønstre på bakgrunn av en satt kunnskapstradisjon. Er det mulig, gjennom skriving som praksis, å tvinge oss til å tenke annerledes? Til å gjentenke selvfølgeligheter for å skape forskyvninger og bevegelser som kan generere nye handlingsmønstre? Hvordan forflytte fokus på det som er til det som kan bli? Her blir begrepet affekt et sentralt analytisk begrep.

\section{Ontologiske mellomrom}

Hvordan blir kunnskap til, og hva er det kunnskap til enhver tid er og gjør? Slik jeg leser Deleuze og Guattari (1987) er ontologi et spørsmål om skapelse, og fordrer, slik jeg forstår det, handling gjennom agentskap. Ser vi da på språk som handling kan skapelse i denne sammenheng sees gjennom skriving som metode. Knyttet til denne skapelsen av mulige ontologiske endringer når skriving som metode tematiseres kunne det vært interessant å diskutere improvisasjon som verktøy til å skape med. Jeg vil derimot bevege meg inn i begrepet affekt som råvare og drivkraft i skapelsens sentrum, som en begjærsdrivkraft som kan åpne opp for bevegelser av uro og tvil. Med affekt menes i denne studien kroppsliggjorte erfaringer, hvor både tenkning, begeistringer, tvil, uro og ambivalens påvirker profesjonsutøvere og skaper produktive innganger til pedagogisk praksis. Affekt i denne sammenheng retter ikke fokus på hva det betyr, men hva det gjør og setter i gang.

Å utfordre etablerte sannheter og handlingsmønstre innebærer å være i tvil, og å være usikker. I norsk sammenheng bruker Søndenå (2004) begrepet kraftfull refleksjon, og beskriver at det kan skape uro, og til og med ubehag. Tidligere vitenskapelige innganger kan sies å bære fram forestillinger om at kunnskap hovedsakelig handler om tenkning, men jeg utfordrer denne forestillingen ved å tenke at når kunnskap blir utfordret griper det inn i sammensatte subjektiviteter, og gjør det mulig å åpne opp for motstand utover tenkning. Et helhetlig menneske bærer med seg yrket i hele kroppen sin, og det er kun slik jeg kan relatere meg til pedagogisk praksis. Kraftfulle refleksjoner kan i så måte bære med seg usikkerhet, en opplevelse som ikke bare kjennes i tankene, men som også involverer kropp og følelser. Det kan på bakgrunn av det tenkes at skriftlige tilnærminger åpner opp for kaosorienterte forståelser. Med kaosorienterte forståelser kan det her tenkes som et brudd med hermeneutisk og fenomenologisk tradisjon knyttet til synet på fortolkning og forståelse. For hvor plasseres denne uroa? I bevegelsen mellom erfaringen som omdreiningspunkt og dekonstruksjon? Eller som overskridelser i bevegelse mellom dekonstruksjon og handling, med 
skrivehistorier som diffraksjonsapparat? Og hvilken betydning kan det få for endring, læring og utvikling? Her opplever jeg Derridas tenkning om différance som interessant. Ordet er en omskriving av begrepet "difference", som betyr forskjellig (Derrida, 2006). Det finnes nok flere, og ulike oversettelser av begrepet différance, men jeg velger å lese det som mellomrommet mellom det som er, og det som kan bli. Og kanskje kan det tenkes at det er akkurat her denne uroa kan plasseres, i mellomrommet? Det handler, slik jeg ser det, om å dekonstruere det man allerede vet, for å skape muligheter til å åpne opp for det som kan komme. Det å være åpen og ønske velkommen det man ikke allerede vet, kan være det vanskeligste av alt hevder Derrida i (Lenz Taguchi, 2004). Denne åpne, flyktige og uforutsigbare tilnærmingen kan, slik Deleuze og Guattari (1987) beskriver, det skape flere ulike innganger og utganger, hvor affekt kan brukes som uttrykk for å fange forandringer. Affekt retter fokus mot hva og hvordan omgivelser påvirker oss følelsesmessig og kroppslig, hvordan kropp og tanke utgjør en helhet. Kropp i denne sammenheng forstås ikke som et humanistisk subjekt, men som en posthuman kropp som gjennom dynamisk affektivitet handler om eksperimenterende posisjoner (Deleuze og Guattari, 1987). Å la seg berøre, eller berøre andre følelsesmessig, er et sentralt perspektiv i dette. Slik sett handler det om å sette opplevelser i sammenheng med hvordan vi reagerer og opptrer kroppslig i møte med noe. Det kan tenkes at Assistent $A$ intra- agerer med Skrivehistorie 1, slik at den affektiv fanger diskursive forandringer. Ut ifra dette kan det tenkes at affekten settes i stand til å endre noe, og på den måten kan sees som en produktiv makt ut ifra dens kraft. Kan skrivehistorier som materialitet gjennom intertekstualitet og dekonstruksjon skape nye tilstander av affekt? Dette muliggjør i så fall forskyvninger og overskridelser i diskursive praksiser, slik Skrivehistorie 2 gir et bilde på denne prosessen som bevegelig praksis:

Det er tidlig ettermiddag like før frukttid. Thea vandrer rundt inne på småbarn, sutrer, - og virker utilpass og lei seg. Hun kommer bort til meg og vil sitte på fanget. Jeg spør om det er noe hun vil fortelle meg. Etter å ha sittet på fanget en liten stund sier hun plutselig: "matboksen min".

Derrida (2006) legger vekt på at språket ikke er en fastlåst lukket konstruksjon, men lar seg bevege og justere ved å utfordre språket. Gjennom skriftliggjøring av egen praksis kan det tenkes at barnehagens innhold og verdier utfordres og understrekes. Dekonstruksjon handler om å utforske hvordan kunnskap og erfaringer er bygd opp, og skriving som metode kan sees som vår praksis for dekonstruksjon hvor vi plukker diskursene fra hverandre for å sette de sammen igjen på nye måter. Dekonstruksjon i denne sammenheng ga oss mulighet i veiledning til å gå inn i Skrivehistorie 1 som materialitet hvor vi kunne undersøke hvordan vår kunnskap er konstruert. Ved å gå inn i skrivehistoriene sammen med personalet utfordres de på å snu, vende, forstyrre og lete frem virkelighetene slik de ligger skjult i det diskursive språket som anvendes. På denne måten snur og vender dekonstruksjonene på de forestillinger vi "tar for gitt". I det vi dekonstruerer og rekonstruerer våre forestillinger bryter vi de ned, samtidig som vi bygger de opp, og på den måten går vi i motstand mot våre egne forestillinger som gir oss handlingsrom til å konstruere nye virkeligheter. Ved å åpne opp for det samtidige ved å bryte dikotomiske forestillinger, og da åpne opp for de forskjellige og ulike forestillinger retter vi fokus mot flere diskurser som mulige innganger. Dekonstruksjonen blir derfor sentral for å synliggjøre hvordan diskurser materialiseres gjennom språket. Gjennom skriving avdekkes kunnskap som gir rom for å undersøke hvordan forestillingene om barn og barnehage er konstruert. Det er interessant å se dette opp mot vårt arbeid med veiledede skrivegrupper hvor vi iscenesetter rom hvor vi kan "forstyrre" det etablerte for å identifisere og befeste foreløpig kunnskap. Inspirert av Derridas tenkning er målet å skape forståelser for nye virkeligheter. Den situerte virkeligheten bryter her med et dikotomisk bilde knyttet til virtuelle bevegelser, ved å tenke hvordan situerte virkeligheter kan (gjen)opplives av virtuelle materialiteter, som skrivehistorier $\mathrm{i}$ denne sammenheng. I det bildet kan vi utfordre tanken om hvordan virkeligheten kan aktualiseres $i$ og gjennom oss, affektivt, samtidig som det bidrar til videre produksjon av virkeligheter- det som kan skje, som enda ikke er kommet. Det affektive, slik jeg forstår Deleuze og Guattari (1987) omhandler ikke kun, eller nødvendigvis følelser, men en kraft og energi, muligens en sammensetning av følelser 
og effekter, som vi ikke er klar over når inntreffer. Vi kan tenke at affekt på den måten ikke forutsetter intensjoner og/eller selvbevissthet, det er noe som skjer, en forandring utenfor vår kontroll, samtidig som vi tar del i det. Kanskje kan vi, gjennom Deleuze og Guattari (1987) forstå affekt som noe i mellom det indre og ytre, som en samling av heterogene deler som gjør noe. Slik sett vil betydningen av affekter ligge i den kraften det skaper, og hvilke tanker og følelser det muliggjør. På den måten kan vi holde virkeligheten i skapende bevegelser, og slik pågår situerte og virtuelle bevegelser samtidig:

Jeg er blitt mer oppmerksom på Thea. Det virker som om hun trenger fysisk nærhet og trøst før hun kan begynne å prate. Jeg prøvde å sette meg mer inn i barnets følelser og opplevelser. For meg var det en viktig vekker. Det som fremstår som sutring er sårhet og sterk frustrasjon hos henne. For å hjelpe henne videre med språket er det nødvendig å ivareta hennes følelsesmessige behov først.

Richardson (2000) beskriver, slik jeg forstår det, det skriftlige språket som en kraft for å oppdage sentrale perspektiver ved virkeligheten, og om seg selv. Gjennom skriving angriper vi våre etablerte sannheter og lar tvil, usikkerhet og kritisk granskning gi oss tilgang til skapende, produktive og forskyvende prosesser. Ny kunnskap sees som foreløpig, og som omdreiningspunkt som lar oss justere og supplere i våre praksiser. Gustavsson (2000) bruker begrepet kunnskaping i den forståelse av at kunnskap innebærer noe kreativt, og at å skaffe seg kunnskap er en aktivitet, som krever bevissthet om å framstille kunnskapen. I den sammenheng kan en tenke at kunnskap ikke består $\mathrm{i}$ objektiv, sann viten, men konstrueres sosialt, virtuelt, materielt og i menneskers bevissthet. Kunnskap kan derfor sies å konstitueres av subjektet, og utvikles diskursivt, materielt og sosialt. Jeg refererer ikke her til materialitet som en iboende, statisk størrelse eller et uavhengig eksisterende objekt. Materialitet refererer i denne sammenheng heller til "phenomena in their ongoing materialization" (Barad, 2007, s. 151), altså må materialiteter inkluderes som aktive agenter $\mathrm{i}$ konstruksjoner av virkeligheter. Begrepet agenter finner jeg interessant her, og jeg vil belyse det ved å gå inn i Barads definisjon av agency som skapende handling: "is a matter of intra- acting; it is an enactment, not something that someone or something has" (Barad, 2007, s. 112). Barad mener at materialiteter og kropp kan sees i en diskursiv sammenheng der begge har aktive agentskap. Agentskap er altså ikke noe bare mennesker har, men også det materielle har evne til å skape mening, forstyrre og påvirke våre pedagogiske praksiser. Slik kan vi tenke skrivehistorier som materielt eksempel hvor våre forestillinger og overbevisninger påvirker vår intra- aksjon med verden og på den måten kan intra- aksjoner også endre de oppfatninger og forestillinger om hvordan vi tilegner oss kunnskap. Dette kan bety at skrivehistorier som materialitet kan ta del i produksjon av makt og forandring i en gjensidig intra- aktiv relasjon om vi evner å utnytte det vi åpner opp for. På denne måten kan vi rette et kritisk søkelys mot selvsagte tankeganger og handlingsmønstre. I forlengelse av dette, omtaler Barad agential realism som et epistemologisk og ontologisk rammeverk, som har til hensikt å se på forholdet mellom det materielle og diskursive, natur og kultur og forholdet de imellom gjennom agentskap. Barad (2007, s. 89) skriver fram agential realism som en omformulering av begrepene agentskap og realisme og forklarer det slik: "Agential realism provides an understanding of the role of human and nonhuman factors in the production of knowledge, thereby moving considerations of epistemic practices beyond the traditional realism versus social constructivism debates".

Å se seg selv som agent i egne praksiser i lys av Barads perspektiv kan åpne mulighetsrom for å aktivt handle og skape, og være i bevegelse med og mot diskursene. Samtidig byr agential realism på innganger til å se hvordan man individuelt og kollektivt skaper kunnskap i møter med skriving som materialitet. Gjennom skriftliggjøring av egen praksis kan man tenke at virkeligheten er ikke først og fremst "der ute". Virkeligheten befinner seg i, med og gjennom oss, og affektivt påvirker våre innganger til (agentskap i) pedagogisk praksis. Ved å oppdage at verden i barnehagen er noe mer enn vi har trodd, kan vårt arbeid med skriving som overskridende metode bidra til et ønske om å utvide 
det vi tror er rammene for virkeligheten vi befinner oss i. Det handler i så måte om hvordan vi gjennom skriftliggjøring av de små og nære hendelser i det levende livet i barnehagen kan dekonstruere dominerende diskurser og bryte etablerte handlingsmønstre, gjennom skriftlige materialer som diffraksjonsapparat (Barad, 2007). Ved å tenke skrivehistorier som diffraksjonsapparat som skaper bølger og brytninger i møte med ulike diskurser og pedagogiske praksiser synes jeg dette eksempelet gir et bilde på hvordan skrivingen forstyrrer våre logiske kunnskapstradisjoner og gir oss mulighet til å øyne mønstre som kan få fram fenomeners foranderlighet (Barad, 2007, s. 84). Målet med diffraksjonsapparatet er derfor, å skape forandring og unders $\emptyset$ ke "[...] the entangled effects differences it make" (Barad, 2007, s. 73). I følge Fairclough (1995) er vi i konstant forandring i den sosiale praksis på grunnlag av kunnskap om gjeldende praksiser, og det vil på bakgrunn av det bli viktig å være bevisst den praksis vi gjør daglig slik at vi skaper eventuelle rom for endring.

"Virkeligheten" kan bare studeres gjennom diskursene, den kan ikke konstituere seg selv, men kan komme til oss gjennom en mediert form (Rønbeck, 2012, s. 17). Vi må utfordre diskursene med nye utsagn i tale, tekst eller handling (Foucault, 1999, s. 33), og slik kan vi tenke at hvordan vi språklig vender blikk mot nye utsagn $i$ tekst og tale kan skape premisser for hvordan vi ser og forstår oss selv $i$ møte med egen praksis. Diskursiv praksis sees som konstituerende, og bidrar til å reprodusere relasjoner, kunnskapsregimer og den sosiale arena, og Foucault (1995) argumenterer for at en bør finne fram til maktens mindre iøynefallende trekk, og lete etter de små og dagligdagse uttrykkene (Rønbeck, 2012, s. 22). Jeg viser her til Barnepleier som skriver: "Den lille situasjonen blir til noe stort når man skriver det ned". Det handler i så måte om å oppdage og gripe tak i kunnskapskildene som hverdagen inneholder.

\section{Kan ordene vi bruker forme vår oppfatning av virkeligheten?}

Kritisk språkbevissthet gir oss tilgang til å bli oppmerksomme på praksis der vi tenker ut ifra etablerte handlingsmønstre, og med en kritisk bevissthet rundt språket i bruk mener Fairclough at vi kan komme nærmere diskursen og eventuelt forandre og se alternativer til å skape nye diskurser (Fairclough, 1995). Jeg synes det er aktuelt å se dette i sammenheng med artikkelen Sommerfugler og IQ-testar -Om språkleg smitte i barnehagen i Barnehagefolk nr. 3/ 2014, hvor Jan Inge Sørb $\varnothing$ reiser en viktig prinsipiell diskusjon om den faglige språkbruken i dagens barnehageverden. "Det går ei direkte linje frå måten ein snakkar om barnet på, og til måten ein handlar når det gjeld barnet språk er alltid handling" (Sørbø, 2014, s. 53). Dette finner jeg svært interessant fordi det kan gi et bilde på hvor transparent diskursiv praksis kan gjøres gjennom skrivehistorier om man forstår språk som handling. På bakgrunn av det kan en tenke at skriving som metode synliggjør barnehagens diskursive praksis, og slik sett kan gi handlingsrom til å dekonstruere den praksis som "tas for gitt". Gjennom skriving skaper vi arenaer for dekonstruksjon og re-konseptualiseringer av egne praksiser. Vi utfordrer innforstått kunnskap og blindsoner. Form, sjanger og innhold varierer, og representerer et mangfold som skaper en positiv uro. Åpenhet og tilblivelser i spenning ses på som en styrke i dette arbeidet, og slik kan organisasjonssprengende praksiser deles. Assistent 2 skriver det fram slik i sine refleksjoner: "Jeg må slutte å definere barna, og være på utkikk for å se om det finnes flere barn som sliter med å bli forstått". Ser vi da overskridelser i et prosessuelt perspektiv hvor endringer skjer i praksis når vi forstår noe nytt eller ser faktiske forhold på andre måter gjennom skriftlige tilnærminger, i tråd med at det går ei direkte linje om måten vi skriver om barn- og handler på (Sørbø, 2014, s. 53), synes jeg de ovennevnte perspektiv gir et bilde på overskridelser i pedagogisk praksis. Barnepleier skriver det slik: "Jeg føler at jeg satte Thea i bås - hun bare sutrer. Gjør jeg det til flere barn? Jeg har blitt bevisst hvor viktig det er at jeg ikke setter dem i bås, men prøver å forstå dem". Det virker nesten overflødig å utbrodere betydningen av personalets oppdagelser som her eksemplifiseres, ordene taler for seg selv og endringer i praksis materialiseres gjennom språket i disse refleksjonene. I et kompetanseutviklende bilde bør vi allikevel identifisere og befeste de 
prosessene vi står i, slik at vi kan oversette og utfordre flere blindsoner vi befinner oss i. Slik beveger vi oss i retning mot en prosessuell barnehagebasert kompetanseutvikling:

\begin{abstract}
The ethnograpical life is not separable from the Self. Who we are and what we can be- what we can study, how we can write about that which we study- is tied to how a knowledge system diciplines itself and its members, its methods for claiming authority over both the subject matter and its members. We have inherited some ethnographic rules that are arbitrary, narrow, exclusionary, discorting, and alienating. Our task is to find concrete practices through which we can construct ourselves as ethical subjects engaged in ethical ethnography- inspiring to read and write (Richardson, 2000, s. 938).
\end{abstract}

\title{
Kunnskaping
}

Ved å bruke posthumane og affektive tilnærminger (Deleuze og Guattari, 1987) som produktive innganger til nyskriving av pedagogisk praksis blir vi, slik jeg leser Deleuze og Guattari, gjennom eksperimenteringer, tatt med på oppdagelsesreiser, langt fra oss selv. Deleuze og Guattari skriver om nomadisk tenkning, det vil si tenkning som forflytter seg i møter, relasjoner og konfrontasjoner hvor eksperimentene åpner opp for kaos og det uforutsigbare, ikke for sikker kunnskap. I motsetning til å være på leting etter et fast utgangspunkt, opplever jeg at Deleuze og Guattari (1987) betrakter kunnskaping som en løpende prosess uten faste start- eller sluttpunkt. Begrepet rhizomet tatt i bruk av Deleuze og Guattari (1987) vil være sentralt her, og en rhizomisk ${ }^{2}$ tilnærming kan i denne sammenheng bli et bilde på et fenomen som forstyrrer logiske kunnskapstradisjoner med den hensikt at å søke forandringer kan åpne opp for at vi som profesjonsut $\varnothing v e r e$ kan bryte med vante pedagogiske tankemønstre. Slik kan vi tenke at det finnes flere ulike innganger og utganger til noe, som kan by på muligheter til å overskride i pedagogisk praksis ved å forstå praksis som en kontinuerlig (til)blivelsesprosess. (Til)blivelsesprosesser opplever jeg gjennom Deleuze og Guattari (1987) som en motsats til det som reproduseres - eller reduseres til det det er, noe som innebærer en bevegelse bort ifra statiske værensspeilinger og dermed åpner innganger til å tenke annerledes om hvem vi er. En rhizomisk utforskning byr derfor, slik jeg ser det, på et konstant spill med det som dekonstrueres, og gir oss handlingsrom for eksperimenteringer. Dette kjennetegner tanker om samtidighet og forskjellighet, perspektiv som bryter med dikotomisk tenkning og åpner opp muligheter og mellomrom. Disse perspektivene er interessante i møte med Derrida (1976) slik han bygger sin tese på at språket innehar skjulte betydninger, différance, som betegner det som fremstår forskjellig fra noe annet. Rhizomen kan i så måte knyttes til begrepet différance og det immanente, ved å tenke slik både Derrida (1976) og Deleuze og Guattari (1987) sier det: alt er alltid. Slik skapes mulighetsrom til å gå inn i mellomrommene i pedagogisk praksis. Målet for vår praksis kan ut ifra det være å tenke hvordan skriving som overskridende metode kan åpne opp for nye kunnskapsinnganger gjennom stadige (til)blivelsesprosesser hvor vi utforsker ulike terreng sammen, igjen og igjen.

Gjennom skrivehistoriene som omdreiningspunkt kan vi altså danne oss et bilde av hvordan vi kan forflytte oss i en bevegelig praksis, gjennom "lines of flights" hvor vi utforsker perspektiv vi muligens tidligere har ignorert, og gjennom skrivehistoriene tenke hvordan overskridelser får betydning for vår praksis ved at vi utgjør en forskjell for barns liv i barnehagen ved å forflytte oss diskursivt. Samtidig kan vi tenke hvordan vi utøver agential realism (Barad, 2007) gjennom skrivehistoriene som materialitet og slik sett utfordrer og opphører skillet mellom natur og kultur. Dette kan forstås som et brudd med vår tradisjonelle, lineære og logiske oppfatning hvor vi i et kompetanseutviklende bilde åpner innganger til å skape ny kunnskap omkring vår egen praksis. På denne måten kan skriving som nomadisk aktivitet synliggjøre og forsterke hvordan vi bryter våre etablerte handlingsm $\emptyset$ nstre ved å opphøre tid og sted. Vi er underveis. Alltid. Å utfordre våre sannhetsfortellinger i praksis innebærer

\footnotetext{
2 Jeg velger å benytte meg av betegnelsen rhizomisk fremfor rhizomatisk, da jeg synes det gir et bedre språklig bilde på skapende produktive bevegelser.
} 
derfor en utvikling av agentskap og på denne måten kan vi skape nye territorier, og gjennom deterritorialisering se verdien av affektive kaosorienterte forståelser som støtter oss i å problematisere og tydeliggjøre vår diskursive praksis. På denne måten kan vi også tenke hvordan skriving som metode åpner for motiverende og dyptgående endringsprosesser og fremstiller virkeligheter gjennom agentskap som en kraft som hindrer vilkårlighet og tilfeldige praksiser.

Disse eksemplene på overskridelser kan ikke alene relateres til skriftliggjøring av egen praksis, men må sees i sammenheng med veiledede skrivegrupper, hvor vi gjennom intertekstualitet skaper premisser for en bevegelig praksis. Gjennom veiledede skrivegrupper oversettes og drøftes materielldiskursiv praksis gjennom skrivehistorier som materialitet, hvor skrivehistoriene intra- agerer med hverandre gjennom intertekstualitet og dekonstruksjon. Dekonstruksjonen blir i så måte sentral for å synliggjøre hvordan diskurser materialiseres gjennom språket, og slik sett kan vi tenke at det gjennom skriving som metode eksisterer en materiell virkelighet av sosiale praksiser, som strekker ut over de diskursive.

Som lærende organisasjon består vårt arbeid i systematisk bevisstgjøring og diskusjon i forhold til de

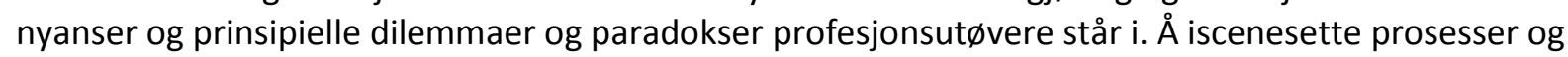
omsette oppdagelser i og gjennom skriving i form av foreløpig kunnskap krever tålmodighet og mot til å stå i langvarige prosesser, det tar tid å identifisere, befeste og synliggjøre kunnskap. Det innebærer en utvikling av agentskap som affektiv betingelse for å åpne rom for endrede handlingsmønstre. På denne måten kan vi forstå hvordan vi kollektivt står i de- autoriserte kunnskapingsprosesser (Derrida, 1976) som former vår tilnærming til barnehagen som lærende organisasjon gjennom utforskning og utprøvinger av skriving som metode. Å utfordre oss på å se barnehagen som en lærende organisasjon fordrer at vi kontinuerlig må drøfte hvordan, og hvorfor vi skal lære sammen, hva vi kan åpne opp for, og ikke minst hvordan vi tar det i bruk.

Jeg retter i denne studien blikket både mot de individuelle og kollektive prosessene barnehagen står i. I så måte vil skriving som metode også aktualiseres i et organisasjonsperspektiv gjennom skriftliggjøring av pedagogisk praksis, hvor diskursive praksiser drøftes når vi sammen skriver for å lære som en lærende organisasjon. Rammeplan for barnehagens innhold og oppgaver, kap.1.7 stadfester at barnehagen som pedagogisk samfunnsinstitusjon må være i endring og utvikling: "Barnehagen skal være en lærende organisasjon slik at den er rustet til å møte nye krav og utfordringer. Kvalitetsutvikling i barnehagen innebærer en stadig utvikling av personalets kompetanse". (Kunnskapsdepartementet, 2011). Med utgangspunkt i Rammeplanens målsetning vil jeg se på hvordan barnehagen som skrivende organisasjon skaper betingelser, og åpner handlingsrom til stadige bevegelser i det barnehagefaglige arbeidet. Vi kan tenke at vi som organisasjon gjennom skriving som overskridende metode iscenesetter læringsprosesser som istandsetter oss, som lærende organisasjon, til å forankre og forandre kunnskap i, om og med våre praksiser. I så måte kan en tenke barnehagen som lærende organisasjon med skriving som overskridende metode som kompetansestrategi. Det vil i sammenheng med barnehagen som lærende organisasjon være $n \varnothing$ dvendig å belyse begrepet læring.

Læring, et begrep som befinner seg på alles lepper, overalt og i ulike sammenhenger. Et begrep som er flittig brukt i styringsdokumenter, men som vanskelig lar seg definere. For hvordan lærer vi? Og vet vi egentlig helt sikkert når læring skjer? Det finnes hyllemeter med teori og litteratur knyttet til læring, og det etableres både læringsverksted og læringssenter i ulike sektorer. Læring sees i ulike former og varianter. Jeg skal være forsiktig med å begrepsavklare læring, det innebærer en viss risiko for å redusere begrepet til noe det er uten en tanke for å åpne opp for hva læring kan bli, og hva det kan gjøre. Det jeg derimot kan forsøke, er å knytte læring opp mot forskjells - begrepet, différance (Derrida, 1976, Barad, 2007), ved å tenke læring som rommet mellom strukturene, hvor vi forstyrrer og skaper brudd med det etablerte, hvor gjentakelser utfordres. Ved å knytte læring til forskjells begrepet kan vi tenke hvordan meninger og kunnskaper kan oppleves som motstridende og usikre 
når vi løfter forskjellighetene i pedagogisk praksis, og slik tenke forskjells - begrepet som en affektiv kraft. Vi kan tenke hvordan vi gjennom skrivehistorier unngår å tenke praksis som "det samme" som vi alltid har gjort. Vi kan tenke at skrivehistoriene allerede er forskjellige fra det de en gang var, og hvordan de gjennom intertekstualitet veves inn i hverandre, og oppstår med og som et mønster av forskjellighet (Barad, 2007, s. 72). Forskjellighetene virker stadig, ved at de blir til gjennom grenseløse møter, med de som skriver og med de som leser. Vi er bevegelige. Og vi er i bevegelse, vi vibrerer slik jeg forstår (Deleuze \& Guattari, 1987). Gjennom å åpne opp, ved å løfte og drøfte blant annet ulikheter og uenigheter, og utforske nye innganger til pedagogisk praksis, skapes det rom for endring og overskridelser i barnehagens faglige arbeid. Kanskje handler det om læring. I så måte settes læringsbegrepet for utprøving gjennom denne studien, kanskje vil de eksemplene jeg viser til gjennom datamaterialet gi et bilde på læring når jeg drøfter betydningen overskridelser og endringer kan ha for pedagogisk praksis, uten at det lar seg gjøre å definere begrepet læring? Kan vi, gjennom posthumane innganger, tenke læring som stadige (til)blivende eksperimenteringer? Det er interessant å se vårt arbeid med skriving opp mot kompetansestrategiens (2014-2020) bruk av begrepet lærende organisasjon som i kapittelet System for kompetanseutvikling omtales slik:

Et kjennetegn ved en lærende organisasjon er at alle ansatte er engasjert i å skape og dele kunnskap om hvordan de best kan nå organisasjonens mål. I slike organisasjoner stimuleres de ansatte til å se ting på nye måter og kontinuerlig utforske hvordan man kan lære sammen (Kunnskapsdepartementet, 2013, s. 11).

Kanskje er det akkurat slik vi lærer, som lærende organisasjon, når vi skriver oss fram i en narrativ praksis. Ved å iscenesette læringsprosesser som oppstår i møte med aktiviteter, og skaper vibrasjoner (Deleuze \& Guattari, 1987), som gjør oss i stand til å finne mulige og fruktbare "lines of flights" og deterritorialiserende bevegelser. På den måten kan vi forflytte oss i skapende praksiser og delta aktivt i skapelsesprosesser, og samtidig undre oss over hvilke transformative konsekvenser dette kan få i produksjon av nye kunnskaper og (til)blivelser. Personalet selv skriver fram barnehagens arbeid med å nå målsetningen om en lærende organisasjon slik i et felles refleksjonsnotat:

Gjennom dette arbeidet blir vi modigere, vi øver oss på å gå ut av komfortsonen vår. Vi får bedre innsikt i hverandres praksis som st øtter oss i å være trygg på å dele med hverandre, og vi utfordres på å være undrende og usikker som støtte til å koble av autopiloten. Slik sett må alle ta ansvar for en felles måloppnåelse.

Når jeg drøfter barnehagen som lærende organisasjon med skriving som metode for kompetansestrategi er det $n \varnothing$ dvendig å diskutere hvordan vårt arbeid kan sees i sammenheng med endringer i styringsdokumenter, slik kompetansestrategien 2014-2020 (Kunnskapsdepartementet, 2013) stadfester at barnehagebasert kompetanseutvikling skjer i barnehagen. Kunnskap skapes $i$ barnehagen, av barnehageansatte - over tid. For å st øtte oss til det teoretiske rammeverket kan vi se det slik Barad (2007, s. 185) skriver det: "We don't obtain knowledge by standing outside the world; we know because we are part of the world in its differential becoming". Barnehagen som lærende organisasjon med skriving som metode for kompetansestrategi åpner, som denne studien gir et bilde på, mulighetsrom gjennom eksperimentering med kunnskapsstrukturer til å styrke barnehagen som pedagogisk institusjon. Det er allikevel nødvendig å påpeke at pedagogisk praksis ikke må forenkles eller undervurderes, men bør sees som et mangfold av samtidige kunnskapstradisjoner. Gjennom Foucaults perspektiv på diskursenes kraft til å utelukke og tilsløre kunnskapstradisjoner (Foucault, 1999) er det ikke mulig å fristille seg fra diskurser, men ved å se kritisk på våre egne forestillinger kan vi bli, slik Førskolelæreren uttrykte seg i sine skriftlige refleksjoner, mer bevisst vårt handlingsrom: 
"Det er på bakgrunn av dette noe lettere å se barnet med nye øyne, og inneha en annen holdning til det".

Richardson (2000, s. 936) omtaler som nevnt skriving som en prosess av oppdagelser, men hvordan reagerer forfatteren på sine egne oppdagelser? Og hva innebærer det å oppdage seg selv i miljø der man diskursivt er plassert og posisjonert? Samtidig kan vi diskutere hvordan vi framstiller oss selv i vår skriving, og med hvilke konsekvenser? Ved å gi ansatte muligheter til å stå i skapende autoetnografiske skriveprosesser ser vi at den enkelte skriver fram seg selv og sitt oppdrag som dynamiske aktiviteter som omgjøres til en kraft som blir gjensidig virksom i utvidede relasjoner (Deleuze \& Guattari, 1987). I så måte kan vi tenke at framskriving mot det aktive subjekt gjennom affektive betingelser forankrer og forandrer gjennom skrivehistorienes materialitet. Gjennom systematisk skriving og kritisk bruk av skrivehistorier for synliggjøring og dekonstruksjon av praksiser skaper vi en arena hvor vi kan utfordre innforstått kunnskap og eventuelle blindsoner.

Når kompetanseutvikling og strategier nevnes er det fristende å la seg inspirere av Steinnes (2006) og hennes syn på utvikling som hun skriver frem i sin doktorgradsavhandling: Den andre skoleporten: om institusjonalisering av den pedagogiske handling, et møte med Jacques Derridas språkkritiske perspektiver. Steinnes (2006) hevder at utvikling må sees som et lineært begrep, og mener transformasjon er mer dekkende i den grad at det omhandler at noe kan bli til noe annet enn det det er, uten at grunnlaget er forandret. Steinnes beskriver transformasjon som en plutselig hendelse som er umulig å kontrollere og som på mange måter er veldig uforutsigbar, slik pedagogisk praksis også kan oppleves. Samtidig kan vi også undre oss over om transformasjon forteller noe mer fundamentalt om det å være menneske, at vi som mennesker ikke utvikler oss lineært fra et nullpunkt, men transformeres gjennom kontinuerlige prosesser i møte med verden. I den sammenheng kan vi tenke oss personalet i barnehagen i møte med verden, med blant annet skrivehistorier som materialitet, hvor vi affektivt blir berørt, det er noe som forandrer oss og gjør at vi på en eller annen måte er annerledes enn $f ø r$ dette møtet med skrivehistorien(e). Det betyr ikke at vi skal forkaste det som er i barnehagen, men vi kan la oss forstyrre. Vi kan, som Derrida og Foucault, tenke at som motsats til å gå i gjentakelser av diskurser kan vi gå i motstand ved å dekonstruere de dominerende diskurser. Derrida (1976) hevdet at det ikke var noen virkeligheter utenfor språket, men at språket konstruerte virkeligheter og kunnskaper. Når skriving som metode tematiseres kan vi tenke at veien til transformasjoner av det som alltid allerede er til stede i våre konstruksjoner av virkeligheter, går gjennom dekonstruksjon av skriften. I dette tilfellet skriften som skrivehistorier. Spørsmålet vil være om vi evner å se pedagogisk praksis som skapende virksomhet slik skriving som metode fordrer i denne sammenheng. Med det som utgangspunkt kan vi stille oss følgende spørsmål: Hvordan sikre transformasjon av personalets kompetanse med utgangspunkt i de strukturelle og komplekse rammene vi står i? Og hvordan sikre sammenhenger mellom individuelle og organisasjonsmessige læringsprosesser gjennom skriving av skrivehistorier hvor diskursive praksiser drøftes?

\section{Barnehagen som det tredje rom}

Erfaringene våre får konsekvenser i den grad at vi nå ser det som avgjørende, og en betingelse for å nå de målsetningene vi har gitt det samfunnsmandatet barnehagen har, å skape en åpen intra- aktiv barnehage, hvor vi gjennom skriving som overskridende metode eksperimenterer med "lines of flights" og skaper innganger til barnehagefaglig arbeid som nye territorier. Slik jeg leser Foucault gjennom diskursive teorier, omhandler diskursive tilnærminger til det pedagogiske feltet å analysere kunnskap og makt gjennom strategier av motstand. Kanskje kan skriving som overskridende metode gjennom skrivehistorier som materialitet og diffraksjonsapparat utfordre oss på akkurat det. Det kan tenkes at barnehagen som skrivende organisasjon blir en strategi for motstand hvor vi bryter med etablerte barnehagefaglige pedagogiske teorier, analyser og kunnskapstradisjoner og samtidig etablerer nye produktive kunnskapsstrukturer og konstruksjoner. Det er viktig å påpeke at jeg ikke 
$\emptyset$ nsker noen dikotomisk fremstilling av etablerte kunnskapssyn og nye teoretiske innganger til barnehagefaglig arbeid, men jeg ønsker å åpne flere innganger og dimensjoner til å forstå kunnskapskonstruksjoner i pedagogisk praksis, slik at vi kan åpne opp for barnehagefaglig kunnskap som bevegelig. På den måten kan deterritorialisering gjennom "lines of flights" i skriving som metode skape nye territorier hvor vi gjennom bevegelser produserer forandring. I forlengelse av dette, gjennom Steinnes (2006) sin tenkning om transformasjon kan vi fors $\varnothing$ ke å se på barnehagen som translokal (Reinertsen, 2016), et sted for transformasjon og overskridelser som vil gi nye bilder av hva dette stedet er. Dette kan knyttes til en tenkning om stedet som det tredje rom som Derrida (2002) skriver om, hvor vi kan tenke hvordan vi kan få øye på hva ny kunnskap kan bidra med når den føres tilbake til stedet, altså barnehagen i denne sammenheng. Det tredje rom vektlegger, slik jeg forstår det, aktiv handling og erfaringer til det stedet man er, og inkluderer både natur, kultur og mennesker og materialer. Derrida skriver fram stedet som et tredje rom som stedet hvor alt kan skje. Et sted som ikke er bare enten/eller, det er mer enn det, det er alt, alltid. Gjennom det kan vi tenke hvordan vi unngår dikotomiske framstillinger av barnehagens pedagogiske praksis. Slik kan vi tenke den translokale barnehage som et tredje rom, og som intra- aktiv, og på den måten framheve forbindelsen læring, overskridelser og endring, gjennom affektive innganger, har til hverandre. På bakgrunn av dette kan personalet i barnehagen selv oppdage overskridelser når kunnskap konstitueres gjennom agentskap. Kan det til og med være slik at vi kan styrke barnehagen som pedagogisk institusjon, gjennom skriving som overskridende metode ved å tenke oss selv som en translokal barnehage? I så måte vil barnehagen, slik jeg knytter det opp mot Derrida (2002), bli til et sted uten et sted, hvor vi alltid er underveis, i møte med det som kommer. Vi kan tenke hvordan barnehagen da blir en foreløpighet av parallelle og samtidige læringsprosesser i møte med skriving som virtuell materialitet. På denne måten kan barnehagen som situert virkelighet (gjen)opplives, igjen og igjen. Gjennom skriftliggjøring av egen praksis, hvor dekonstruksjon konstruerer nye forståelser, byr skriving som overskridende metode på en inngang til å åpne opp for flere tolkninger slik at barnehagen som skrivende organisasjon blir et bilde på bevegelige og stadig (til)blivende praksiser:

Lodge yourself on a stratum, experiment with the opportunities it offers, find an advantageous place on it, find potential movements of deterritorialization, possible lines of flights, experience them, produce flow conjunctions here and there, try out continuums of intensities segment by segment, have a small plot of new land at all times (Deleuze \& Guattari, 1987, s. 178).

En slik tenkning knyttet til bevegelige praksiser vil innebære å skape motstand mot dominerende diskurser, og ser vi dette i møte med kompetansestrategier vil ansvaret ligge i de kollektive strukturene. Hvordan kan vi nytenke pedagogisk kunnskapsstruktur og la oss forstyrre i vår lineære kunnskapstenkning? Er det mulig å skape en rhizomisk kunnskapsstruktur i barnehagen? Kan vi eksperimentere med overskridende prosesser i skriving for å utfordre profesjonsut øvere til å evne å stå i mellomrommet mellom det som er, og det som kan bli? I så måte må vi skape nye konseptualiseringer og $\varnothing$ kte forståelser, men oppheve dem i det $\varnothing$ yeblikket de finnes.

Vi kan tenke at vi gjennom skriving i veiledede skrivegrupper skriver oss inn i et fellesskap som kollektivt identifiserer og befester vår foreløpige kunnskap. Diskusjonen blir hvorvidt barnehagen som organisasjon evner å legge til rette for en delings - og undringskultur hvor kunnskap artikuleres, anvendes og sirkulerer i organisasjonen. Forskning (på egen praksis) handler om å skape ny kunnskap, og gjennom skriving som overskridende metode ser vi gjennom denne studien hvordan kunnskap som skapes kommer fra praksisfeltet selv. Den kunnskapen som skapes bidrar til endring i og gjennom individuelle og kollektive prosesser. Barnehagen kan på bakgrunn av det sees som et sted for læring gjennom skriving som overskridende metode hvor motstridende oppfatninger kan møtes ved å skape en arena hvor profesjonsut øvere selv kan få innflytelse gjennom aktiv handling. Slik kan vi tenke at stedsbasert læring vektlegges som grunnlag for endring og på denne måten 
utfordrer tidligere læringsstrukturer. Skriving som overskridende metode kan da sees som vår inngang til endrings - og læringsprosesser gjennom felles agentskap hvor vi kan oppdage hvordan diskurser utøver makt, og hvordan makten virker på egen praksis og på barnehagen som pedagogisk institusjon og lærende organisasjon. Jeg har argumentert for at skriving som metode kan åpne for aktive og agentiske innganger som i større grad kan ivareta det dynamiske ved barnehagens hverdagsliv. Det er nødvendig å påpeke at dette innebærer et stort ansvar for profesjonsut $\varnothing v e r e$, et ansvar for de endringene som kommer.

Gjennom inngangene jeg har åpnet og gått inn i, kan vi muligens forstå oss selv som rhizomiske forskere på eget praksisfelt hvor bevegelige prosesser gir handlingsrom til å stadig forflytte oss nomadisk. Et spennende perspektiv som muliggjør en tenkning om at personalet i barnehagen fremtrer som aktive medskapere av kunnskap på barnehagefeltet. En rhizomisk tilnærming som posthuman inngang til pedagogisk praksis vil i forskningsøyemed framstå som utradisjonell $i$ akademisk kontekst, og i artikkelen Becoming Rhizome Researchers publisert i Reconceptualizing Educational Research Methodology 2013,4(1) skriver artikkelforfatterne Bryan Clarke og Jim Parsons frem rhizomisk tilnærming som en drivkraft og et $\emptyset$ nske om å tillate seg å gå ukjente veier fremfor stadige kategoriseringer og ideologiske representasjoner av både forskning og pedagogisk praksis. I artikkelen beskriver de hvordan rhizomiske innganger, for forskere og profesjonsut $\varnothing$ vere i pedagogisk praksis, kan legge premisser for hvordan man åpner opp og utvider perspektiv i lærings- og kunnskapingsprosesser. Artikkelforfatterne anser disse ukjente veiene som innganger til agentskap med den hensikt å overskride ved å gå utover lineær tradisjonell tenkning, og slik kan vi forstå oss selv som profesjonsut $\varnothing$ vere med et $\emptyset$ nske om "becoming rhizome researchers". I artikkelen presenterer forfatterne sin tenkning basert på lærere og elever i pedagogisk praksis ved å tenke hvordan rhizomiske innganger kan åpne opp for å oppdage muligheter til utprøving av praksis, til å gå i motstand mot hva vi alltid har gjort og det vi har "tatt for gitt" $i$ tråd med styringsverktøy og læringsmål. De skriver det slik: "each day explores opportunities to try new ideas, to work in the middle synthesizing student interests and curriculum goals". De beskriver dette i et rhizomisk bilde for både forskere og profesjonsut $\varnothing$ vere som jeg ser i sammenheng med pedagogisk praksis $\mathrm{i}$ barnehagen hvor pedagoger forholder seg til lovverk og forskrifter, med læringsmål for barn i barnehagen som første del i utdanningsløpet.

Rhizomiske forskere kan sies å ha en verktøykasse som kan åpne for "lines of flights" med den hensikt å berike pedagogisk praksis ved å bryte med det etablerte. Å stå i det åpne vil være sentralt, og slik kan vi se på praksis som Clarke og Parsons beskriver det gjennom Deleuze og Guatarris tenkning om (til)blivelse: "day-to-day experiential learning". Slik kan jeg forstå meg selv som profesjonsut $\varnothing v e r$ med en drivkraft om stadige (til)blivelser fremfor gjentakelser og kopiering av det allerede erfarte. Selv om vi forholder oss til styringsverktøy kan vi utfordre oss på å finne, og gå inn i mellomrommene ved å følge mulige "lines of flights". Og hva kan det åpne opp for? Artikkelforfatterne skriver det slik: "Ideally, lines of flights can move students towards positive new outcomes in ways that might change a stagnant classroom to a place of expectation". Ser vi dette i en barnehagefaglig kontekst kan overskridelser få betydning for barnehagens pedagogiske praksis ved å nytenke hva barnehagefaglig arbeid kan bli om vi åpner opp for å se oss selv som rhizomiske forskere på eget praksisfelt. Dette finner jeg sammenhengende med perspektivet om den translokale barnehage, og kanskje nettopp slik fordrer den translokale barnehage profesjonsut $ø$ vere som (til)blivende rhizomiske forskere på egen praksis. Gjennom dette perspektivet kan vi tenke barnehagen ultimativt opplevd som en faglig interessant arbeidsplass, som jeg finner relevant $\mathrm{i}$ sammenheng med NOVA Notat, nr.01.15 Barnehagelærerne. Yrkesgruppen som sluttet å slutte hvor Guldbrandsen (2015) peker på betydningen av barnehagen, slik jeg forstår det, som en livgivende arbeidsplass, sett i et affektivt perspektiv. Kanskje kan vi forstå betydningen av å være rhizomiske forskere på eget praksisfelt slik Clarke og Parsons skriver det: "Perhaps the joy of research is ignited when the responsibility to make things happen is let go" (Clarke \& Parsons, 2013). Vi kan se dette som en fordring til å åpne framtiden, eller å la framtiden stå åpen. Slik kan vi tenke en åpenhet for 
hva kunnskaping i barnehagen kan bli, gjennom Derrida som skriver: "If I clearly saw ahead of time where I was going, I really don't believe that I should take another step to get there" (Trifonas, 2000, s. 181). Denne artikkelen har derfor ingen konklusjon i tradisjonell forstand, jeg vil heller si at jeg setter følgende emne for utprøving: Hvordan åpne opp for forstyrrelser og spenninger som produserer nye horisonter i møte med en ny tid? Hva kan vi åpne opp for ved å tenke barnehagen som skrivende organisasjon? Er det umulig å tenke at kunnskapsautonomi i et materielt-diskursivt perspektiv kan løftes fram som en betingelse for utvikling av barnehagen som en lærende organisasjon? Ikke fordi jeg ønsker et oppgjør med det som er, men som et $\emptyset$ nske om å bli en del av en virtuell bevegelse, en som tar fra det som ennå ikke er. På den måten kan også jeg utfordre tanken om hvordan virkeligheten kan aktualiseres i og gjennom oss, affektivt, samtidig som det bidrar til videre produksjon av virkeligheter- det som kan skje, som enda ikke er kommet.

\section{Referanseliste}

Barad, K. (2007). Meeting the universe halfway: quantum physics and the entanglement of matter and meaning. Durham: Duke University Press. http://dx.doi.org/10.1215/9780822388128

Clarke, B. \& Parsons, J. (2013). Becoming Rhizome Researchers. Reconceptualizing Educational Research Methodology, 4(1), s. 35-43. http://dx.doi.org/10.7577/rerm.685

Deleuze, G. \& Guattari, F. (1987). A thousand plateaus: capitalism and schizophrenia. Minneapolis, Minn.: University of Minnesota Press.

Derrida, J. (1967/1976).Of Grammatology. The John Hopkins University Press. Baltimore and London.

Derrida, J. (2002). Lovens makt: "autoritetenes mystiske grunnlag" (B. C. Ekeland, Overs.). Oslo: Spartacus.

Derrida, J. (2006). Dekonstruksjon: klassiske tekster i utvalg. Oslo: Spartacus.

Ehn, B. \& Klein, B. (1994). Från erfarenhet till text: om kulturvetenskaplig reflexivitet. Stockholm: Carlssons.

Fairclough, N. (1995). Critical discourse analysis: the critical study of language. Harlow: Longman.

Foucault, M. (1999). Diskursens orden: tiltredelsesforelesning holdt ved College de France 2. desember 1970. Oslo: Spartacus forlag

Guldbrandsen, L. (2015). Barnehagelærerne. Yrkesgruppen som sluttet å slutte. NOVA Notatnr. 01.15, ( Oslo, NOVA/HIOA).

Gustavsson, B. (2000). Kunskapsfilosofi: tre kunskapsformer i historisk belysning. Stockholm: Wahlström \& Widstrand.

Lenz Taguchi, H. (2010). Going beyond the theory: practice divide in early childhood education: introducing an intra-active pedagogy. London: Routledge.

Kunnskapsdepartementet. (2011). Rammeplan for barnehagens innhold og oppgaver. Oslo: Kunnskapsdepartementet.

Kunnskapsdepartementet. (2013). Kompetanse for framtidens barnehage. Oslo: Kunnskapsdepartementet.

Lenz Taguchi, H. (2004). In på bara benet: en introduktion till feministisk poststrukturalism. Stockholm: HLS förlag.

Nordin-Hultman, E. (2004). Pedagogiske miljøer og barns subjektskaping. Oslo: Pedagogisk forum.

Rhedding-Jones, J. (2005). What is research? : methodological practices and new approaches. Oslo: Universitetsforlaget.

Rhodes, C. (2001). Writing organization : (re)presentation and control in narratives at work. Amsterdam: John Benjamins Publishing Company. http://dx.doi.org/10.1075/aios.7

Reinertsen, A. B. (2015). Uten store ord. I A. B. Reinertsen, \& A. M. Otterstad (Red.), Metodefestival og Øyeblikksrealisme: eksperimenterende kvalitative forskningspassasjer (s. 265-294).

Bergen: Fagbokforlaget. 
Reinertsen, A. B. (2016). The A/Un/Grammatical Chils/hood/s and writing: Nature/culture edusemiotic entangling with affective outside encounters and sustainability events- to come. Global Studies of Childhood DOI: 10.1177/1077800416643998

Richardson, L. (2000). Writing: A Method of Inquiry. I N. K. Denzin, \& Y. S. Lincoln (Red.), Handbook of qualitative research (2. utg., s. 923-949). Thousand Oaks, Calif.: Sage.

Richardson, L. \& St.Pierre, E.A. (2005) Writing: A Method of Inquiry. In Denzin, N. K. and Lincoln,Y.S. Handbook of Qualitative Research. Third Edition. (pp. 959-978). Thousand Oaks. Sage.

Rønbeck, A. E. (2012). Inspirert av Foucault: diskusjoner om nyere pedagogisk empiri. Bergen: Fagbokforlaget.

Steinnes, J. E. (2006). Den andre skoleporten: om institusjonalisering av den pedagogiske handling, et møte med Jacques Derridas språkkritiske perspektiver. Trondheim ,: Norges teknisknaturvitenskapelige universitet, Fakultet for samfunnsvitenskap og teknologiledelse.

Søndenå, K. (2004). Kraftfull refleksjon i lærarutdanninga. Oslo: Abstrakt forlag.

Sørbø, J. I. (2014). Sommerfugler og IQ-testar - Om språkleg smitte i barnehagen. Barnehagefolk, 2(3), 53-57.

Trifonas, P. P. (2000). The ethics of writing: Derrida, deconstruction, and pedagogy. Lanham, Md.: Rowman \& Littlefield. 